\title{
THE DEBATE ON THE IMPLEMENTATION OF NE BIS IN IDEM PRINCIPLE IN HANDLING THE CORPORATE CRIME IN INDONESIA
}

\author{
Timbo Mangaranap Sirait ${ }^{*}$
}

\author{
Criminal Law Department, Faculty of Law Universitas Katolik Parahyangan \\ Jalan Merdeka No. 30, Bandung, West Java, 40117
}

\begin{abstract}
Since the issuance of Temporary People's Consultative Assembly Decree - TAP MPRS No. XXIII/66 until the Reformation era, the participation of strategic multinational corporations is needed for the development. However, in doing their activities, there was a corporation who committed bribery whose criminal law jurisdiction is related to Anti-Bribery FCPA of America. Although the bribery beneficiaries were sentenced in Indonesia because of the locus and tempus delicti of the crime was in Indonesia, since such corporation was convicted first in the US, the corporation is no longer able to be prosecuted in Indonesia because of Ne Bis In Idem.
\end{abstract}

Keywords: jurisdiction, criminal act, corporate, ne bis in idem.

\section{Intisari}

Sejak terbitnya TAP MPRS No. XXIII/66 hingga era Reformasi, partisipasi korporasi multinasional dalam pembangunan sangat strategis diperlukan. Akan tetapi dalam kegiatannya ada korporasi melakukan tindak penyuapan yang yurisdiksi hukum pidananya ada titik-taut dengan Anti-Bribery FCPA Amerika. Walaupun penerima suap sudah divonis di Indonesia karena locus dan tempus delicti adalah Indonesia, tetapi karena korporasi penyuap mendadak lebih dahulu diputus bersalah di Amerika, telah berimplikasi korporasi tersebut tidak dapat lagi diadili di Indonesia karena Ne Bis In Idem.

Kata Kunci: yurisdiksi, tindak pidana, korporasi, ne bis in idem.

\section{Pokok Muatan}

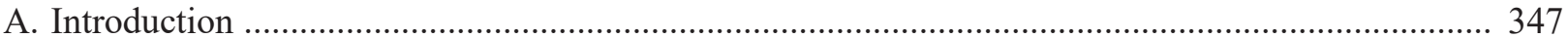

B. Discussion

1. The Sociology Development of Bribery Crime in Global Corporation Business Activity and Its Solutions in Indonesia

2. State's Jurisdiction to Prosecute in the Enforcement of Corporate Criminal Liability in Indonesia and the United States

3. The Position of Ne Bis In Idem Principle in National and International Criminal Law

4. The Criminalization of Bribery Perpetrator associated with the Principle of Ne Bis In Idem .... 355

C. Conclusion 360 


\section{A. Introduction}

Since the era of the issuance of Temporary People's Consultative Assembly Decree (TAP MPRS) No. XXIII/66 on the Renewal of Policy on Economic Foundation of Finance and Development that is aimed among others to process the potential economic power to be a real power through the investment, technology application, knowledge augmentation, skill enhancement, the development of organizational skill and management, from the reformation era until today has made multinational corporations have strategic role in influencing the national economic growth and development.

There are many positive impacts that arise from the entry of such multinational corporations taking role in the development. However, besides of such positive effects, in fact, there are varies of negative impacts that also arise in the operation of such multinational corporations. They distort the principles of national and international criminal law. There are often corporations that take the shortcuts that contribute to the distortion of law enforcement in Indonesia by neglecting business etiquette and the good corporate governance ${ }^{1}$ and actively involved in criminal act of bribery against the state administration, for instance: it is started from the bribery in the process of corporate licensing administration until the bribery to obtain government projects, like what happened in a bribery criminal case against the member of the House of Representatives that "[...] finally convicted with three-years imprisonment and fine in the amount of 150 million rupiahs as a subsidiary of three months detention."

"EM" was sentenced by the Judge panel in Jakarta Corruption Court as he was proven guilty receiving \$357.000 USD gift from Alst. Power Inc US and Japanese M Corporation related to the project of a steam-electric power plant. ${ }^{2}$ The countermeasure of a corporate crime in countries is different depends on the criminal law systems applied in the relevant states. Therefore, there is certainly a differentiation in implementing the criminal sanction to abolish and counter the corporate crime both in common law system or civil law. ${ }^{3}$ In Indonesia Criminal Justice System that adheres the civil law system and in Article 76 of Indonesian Criminal Code (KUHP), it is regulated the principle of Ne Bis In Idem and the criminal sanction of corporate crime for the perpetrator of bribery against the civil servant and the state administration is included into the lex specialis of criminal law provisions for the eradication of corruption crime.

Whereas pursuant to the US Criminal Justice System that applies the common-law system, there is also the principle of double jeopardy that is similar to ne bis in idem as stipulated in the fifth amendment of US Constitution. Consequently, the criminal act of bribery and corruption by corporation towards politicians and foreign state administration abroad is regulated under Anti-Bribery Foreign Corrupt Practices Act (Anti-Bribery FCPA). The United States as "... the Anglo-Saxon state uses the direct liability doctrine or identification theory in which the action/misdemeanour of the senior "officers" is identified as the action/misdemeanour of the corporation. It is also called as alter ego theory/ doctrine or organ theory. In the United States, it is not only the senior official/ the director, but also the agents in his subordinate. ${ }^{4}$

Talking about the criminal liability will

\footnotetext{
According to the State Minister Decision/ The Head of Investment Body and State-Owned Enterprise Development No: Kep-23/M-PM. PBUMN/2000, what is meant by the Good Corporate Governance is a "Healthy corporate principle that is needed to be applied in company management, which is solely performed to maintain the interest of the company to achieve the intent and purpose of the company. (Muskibah, “Tanggung Jawab Direksi dalam Penerapan Prinsip Good Corporate Governance”, Jurnal Ilmu Hukum, Vol. 2, No. 3, 2010, p. 128).

Komisi Pemberantasan Korupsi, "Emir Moeis Divonis 3 Tahun Penjara', http://www.kpk.go.id /id/berita/berita- sub/ 1794, Emir Moeis divonis 3 tahun penjara, last access on 24 December 2016.

Grace Yurico Bawole, "Penerapan Sistem Hukum Pidana Civil law dan Common Law Terhadap Penanggulangan Kejahatan Korporasi," Jurnal Lex Crimen, Vol. III, No. 3, May-July 2014, p. 75.

4 Eddy Rifai "Perspektif Pertanggungjawaban Pidana Korporasi Sebagai Pelaku Tindak Pidana Korupsi," Jurnal Mimbar Hukum, Vol. 26, No. 1, February 2014, p. 94.
} 
be also related with the perpetrator of the crime. ${ }^{5}$ The Corporation as the bribery perpetrator as well as the bribery beneficiary who conduct the crime in Indonesia, per Article $2 \mathrm{KUHP}^{6}$ "shall collaboratively" be liable according to Indonesian Criminal Law. However, while the bribery beneficiary was sanctioned in Indonesia court, on the spur of the moment the M Corporation, as the bribery perpetrator was examined and proven guilty before the Department of Justice of the United States “... M Corporation, a Japanese trading company involved in the handling of products and provision of services in a broad range of sectors around the world, including power generation, entered a plea of guilty for its participation in a scheme to pay bribes to high ranking government officials in Indonesia to secure a lucrative power project ... and announcing that "M Corporation" pleaded guilty to engaging in a seven year scheme to pay and conceal bribes to a high ranking member of Parliament and other foreign officials in Indonesia. ${ }^{7}$ Through such judgment, M Corporation had agreed to pay a criminal fine of $\$ 88$ million USD.

With the spirit of nationalism and anticorruption, the debate of the arguments from the legal scholars arises over such case, inter alia "[...] Anti-Corruption Commission (Komisi Pemberantasan Korupsi - KPK) is supposed to solve all corruption cases in the country without discriminating, including in uncovering the bribery case of "M Corporation" in Tarahan, Lampung steam-electric power plant." "[...] in the case of M Corporation, KPK shall use the recognition to the US Court that has imposed a penalty of $\$ 88$ million USD. "Such recognition is an authentic proof for KPK to investigate it". ${ }^{8}$ There is also an opinion that KPK can investigate a foreign company is known has done a bribery act to the Indonesian officials. Furthermore, the bad practice of M Corporation has been done for years in Indonesia. If KPK can reveal the case, there will be a revelation to the root of the Indonesia corruption cases. "The investigator can use the Law on Corruption Eradication and KUHP. "[...] there is no reason for KPK to delay the examination and investigation towards M Corporation. Besides, it is known that $\mathrm{M}$ has been fined $\$ 88$ million USD by US Court since it is proven bribing when doing its business in Indonesia." The judgment of US Court is based on the confession of M Corporation itself. Thus, such guilty plea becomes a proof for KPK to conduct investigation instantly".9

The prosecution of Japanese M Corporation in Criminal Justice System in the US has become a legal problem and wounded the territorial principle in Indonesian criminal law. This territorial principle shows that anybody who does a criminal act in the territory where the criminal law takes effect, he shall subject to such law. It can be said that all countries embrace this principle, including Indonesia. What becomes the benchmark is the territory or region, whereas the person (corporation) is not questioned. This territorial principle is stipulated in Article 2 of KUHP which says, "The Indonesian statutory penal provisions apply to any person who is guilty of a criminal act (strafbaar feit) in Indonesia. It means that the person who has done such criminal act is not necessarily be physically there, but the criminal act (strafbaar feit) has happened within the Indonesian territory. ${ }^{10}$ Under the current international law, a State has a certain limitation in implementing jurisdiction against a case that is involving the interest of other State. ${ }^{11}$

Sociologically, the criminal act of bribery by a corporation is not a new matter. It has even created

\footnotetext{
Eddy O.S. Hiariej, 2016, Prinsip-prinsip Hukum Pidana, Edisi Revisi, Cahaya Atma Pustaka, Yogyakarta, p. 153.

Article 2 of KUHP stipulates "The Indonesian statutory penal provisions apply to any person who is guilty of a criminal act in Indonesia.".

United States Department of Justice, "Marubeni Corporation Agrees to Plead Guilty to Foreign Bribery Charges and to Pay an \$88 Million Fine", last access on 24 December 2016

Koran Jakarta, “KPK Mesti Tuntaskan Kasus Marubeni”, last access on 24 December 2016.

Ibid.

Andi Hamzah, 2008, Asas-asas Hukum Pidana, Rineka Cipta, Jakarta, p. 66

Stephen Wilske, dan Theresa Schiller,"International Jurisdiction In Ciberspace: Which States May Regulate The Internet", Federal Communications Law Journal, Vol. 50, Issue 1, 1997, pp. 117 and 171.
} 
a bad business climate globally in the business world which has been criticized as a pandora box for the corporation. The problems that are raised through this writing are; How is the sociological development of the corporate crime globally and what are the short, medium, as well as a long-term solution for Indonesia? If there is a case that has a link with an international case, how to determine the jurisdiction related to the crime scene (lex loci delicti commissi) that is applied to hold the corporation accountable for the conducting a corporate crime in Indonesia and the United States? How is the position of $\mathrm{Ne}$ Bis In Idem principle in the national and international criminal law in its relation to the territorial and universal principle? How is the legal implication of the US guilty judgment towards the criminal liability of M Corporation, considering the locus and tempus delicti, as well as the victim of the case, is the State of Indonesia? Is the multinational corporation as the bribery perpetrator not able to be prosecuted in Indonesia because it has been prosecuted in the other State in the same case, in conjunction with the Ne Bis In Idem principle?

\section{B. Discussion}

\section{The Sociology Development of Bribery Crime in Global Corporation Business} Activity and Its Solutions in Indonesia

The development of the business world and the regulation of the liability of corporate crime $^{12}$ before the World War II and after the end of World War II (7 May 1945), had been mutating paradoxically. The rise of wars between nations before the end of the second World War which was supported by the capitalism spirit ${ }^{13}$ initiated by modernism, had made money as the orientation of corporation business on such era. Using the business philosophy of "I am giving to you so that you can give back to me (do ut facias)", ${ }_{14}^{14}$ there were many multinational corporations took part as the logistic suppliers for the military necessities, weapons industry and defence. ${ }^{15}$ However, they considered the war as a business without making any deeper thought that such involvement in the end would only make humans and the humanism became the primary victim of such war.

After the Second World War ended and the science technology became advanced, the nations' paradigm had changed through the born of the developmentalism ${ }^{16}$ almost in all around the world, including in Indonesia. Consequently, the business fields became varies, and the business competition among the corporations were getting sharper. The business philosophy of multinational corporation that previously considered "war is business," completely transforms into "business is war" by refining the business target from previously money oriented into the profit oriented. ${ }^{17}$ As a result, there were many executives or corporate agents that justified any means, including doing the criminal act

12 In 1886 there had been already regulation and prohibition for the corporation management. After the World War I, it was regulated that a crime could be done by a corporation. During and after the World War II, a corporation cumulatively could be held liable according to the criminal law. See Eddy O.S. Hiariej, Op. cit., pp. 199-200.

13 Capitalism as the only sense to initiate the success of modernity, and boost the economic competition, rewards giving and taking is the typical logic of capitalism economic. Such logic was criticized by Jacques Derrida because of the loss of the gist of sincerity and individual responsibility in the exchange, and it was a tragedy resulted from an economic logic. (see, Bambang Sugiharto, et.al., 2013, Humanisme dan Humaniora, Matahari, Bandung, pp. 265-267).

14 Satjipto Rahardjo, 2006, Ilmu Hukum, Citra Aditya Bakti, Bandung, p. 193.

15 There were many multinational corporations involved to become military weapons and logistic supplier during the World War, for example, among others: Corporation of C.G. Haenel Waffen und Fahrradfabrik CITEFA, Kalashnikov, Messerschmitt, BMW AG, Auto Union, and others (see, Gilang Aji Putra, “Apa Sebenarnya Penyebab Kekalahan Jerman di Perang Dunia II?, Kompas, m.kompasiana.com/gilangajiputra/ apa-sebenarnya-penyebab-kekalahan-jerman-di-perang-dunia-II, last access on 19 December 2016).

16 Developmentalism is a multidisciplinary that makes the development as the main strategic to obtain economy prosperity (Wikipedia, "Developmentalisme", https.//id.m. wikipedia.org.wiki.developmentalisme, last access on 19 December 2016) and in Indonesia, it is initiated through TAP MRPS No XXIII/ 1966 on the Renewal of Policy on Economic Foundation of Finance and Development that becomes the beginning of the development era of the developing law and the legal theory of "developmentalism" that later becomes the ideological foundation of the development in Indonesia.

17 Implied from the opinions of the lawmakers $(M v T)$, Molenggraaff, Polak, R. Soekardono that from a part of their arguments, it clearly emphasizes the elements of a company is to look for profits, and the calculation of loss and profit without mentioning the benefit for all people (see, Sentosa Sembiring, 2014, Hukum Dagang, Citra Aditya Bakti, Bandung, pp. 12-13). 
of bribery to the foreign state administration to win the business competition. Simon and Eitzen wrote that "the Senate has revealed that between 1945 and 1976 approximately 350 American corporations have admitted to making bribes of some 750 million dollars to officials of foreign governments". ${ }^{18}$

The Document of the $9^{\text {th }}$ United Nations Congress in 1995 states: The Association of the criminal corporation or individual might have been involved in the "making of bribe to the officials" for various reasons that not all of them have economic value. In fact, in many cases, there is still a bribe to achieve economic profit. The purpose is to persuade the officials to give preferential treatment, among others: ${ }^{19}$ (a) Awarding a contract, (b) Expediting a license, (c) Making exceptions to regulatory standards turning a blind eye to violations of those criteria.

The more skilled the executive or agent of a multinational corporation to make a collusive and bribery approach, packed with the terms to the foreign officials: fee for marketing, entertainment, arranger, etc., so that they can win the competition and obtain various projects in a territory of a certain country, such corporation will be crowned as a prominent corporate; that later, together with other corporation will make consortium to work and win the new projects of the government, although such corporation sometimes only becomes a sleeping (passive) partner in such project. Nick Kochan and Robin Goodyear stated that some Western corporation tends to consider the corruption practice as a cultural tradition from certain countries, particularly, in the developing States. The executive thinks that in a certain territory, with certain people, corruption is something acceptable. The bribery is a crime, but it is needed or considered as an unofficial tax to be able to operate in the certain area. ${ }^{20}$
For the corporation, the occurrence of bribery by the corporation is not something desired, but the executive of the corporation is forced to do so, since the legal condition and the laws and regulations (das sollen) stated that a bribery against the state officials is an action that is in contrary with Indonesian criminal law as stipulated in the Law No. 31 of 1999 jo. The Law No. 20 of 2001 on Corruption Eradication, as well as the United States Anti-Bribery Foreign Corrupt Practices Act (FCPA). However, because in the practice (das sein) of the administration of various corporate licensing administrations, including the tender requirements that are intentionally created to establish a devious public administration, thus, the corporation assumes that the crime act of bribery happens because of condition sine qua non, ${ }^{21}$ and cannot be avoided if the corporation wants to survive in business competition.

Further mentioned by Nick Kochan and Robin Goodyear, a corporation is the same as a State. Internally, it perhaps avoids the ambiguous moral practice (double standards), but in its application, such ethics standard in a foreign transaction is questionable. Faced with the corrupt officials who are intentionally delaying the process through inefficient public administration, the company is forced to pretend not to know the action of its representative or subsidiary to accelerate their business transaction. ${ }^{22}$ Torringa, regarding this relationship stated that there is a presence of "psychological atmosphere" (psychesch klimaat) which applies to a legal institution. It is reminiscent of a closed company with twin management (koppelbazen B.V) which is established to make disturbance (op belazeren is ingericht). It can also happen in a transportation company if there is thought that the company cannot run without

\footnotetext{
J.E. Sahetapy, 1994, Kejahatan Korporasi, Refika Aditama, Bandung, p.6. 
violating the law on "the time limitation for vehicle usage" (rijtijdenwet). Hence, by assessing such reality, the company cannot run its business. ${ }^{23}$

These dilemmatic problems have long been complained by the corporations, and to settle these classic problems, Indonesian government through its mentality revolution program has tried to take several strategic steps as a solution. For instance, for the short-term solution, the government has eased the administration for investment of corporate licensing which is done integrally through one stop service - Pelayanan Terpadu Satu Pintu (PTSP) in Indonesia Investment Coordinating Board - Badan Kordinasi Penanaman Modal (BKPM). Established on 26 January 2015 and until 8 January 2016, it has issued 17.238 licenses. ${ }^{24}$ This one-stop service is a systematic revolutionary for the administration of corporate business licensing for those who are doing their business and investment in Indonesia. It was previously corruptive and had to be done though varies of ministries' departments both in central or regional. It was later changed fundamentally to be systematic and integral as one stop service.

Further, for the medium-term solution, the government follows it up by issuing a policy in reforming the law through Presidential Regulation No. 87 of 2016 on The Special Task Force to Eradicate Illegal Levies - Satuan Tugas Sapu Bersih Pungutan Liar (SABER PUNGLI). For the longterm solution, the writer is suggesting and hoping that there will be a revolutionary reformation for the systematization of law enforcement regarding corporate crime, from its legal substance, legal structure, or legal culture which is done integrally as the implementation of Pancasila's philosophies and for the creation of legal certainty with social justice.
2. State's Jurisdiction to Prosecute in the Enforcement of Corporate Criminal Liability in Indonesia and the United States

Every State has regulation on the jurisdiction to prosecute to enforce the criminal liability towards a corporation which allegedly has done a criminal act in its territory. The jurisdiction to prosecute which is performed in a State like Indonesia and the United States is always regulated in the stipulation of each criminal law, together with its principles that are acknowledged universally. As has been stated by D.P. O'Connel who concludes the jurisdiction as: "[...] the power of a sovereign to affect the rights of persons, whether by legislation, executive decree or by the judgment of a court". ${ }^{25}$

Talking about the criminal liability cannot be separated with the criminal act, although the definition of the criminal act itself does not include the definition of the criminal liability. The criminal act only refers to the prohibition of a certain act. ${ }^{26}$ Whereas the criminal liability itself is the continuation of objective reproach on the criminal act and subjectively towards someone who is eligible to be sentenced for his criminal act. ${ }^{27}$ The stages of settling a corporation as the subject of a criminal act is also impacted to the position of such corporation as the initiator and the character of the corporate criminal liability stipulated in the laws, namely; there are three types of corporate criminal liability: (a) The management of the corporation as the initiator and the corporate manager shall be held liable; (b) The corporation as the initiator and the corporate manager shall be punished; (c) The corporation as the initiator and shall be liable as well. ${ }^{28}$ In Indonesia, the criminal act of bribery by a corporation to the officials or state administration

\footnotetext{
Muladi, and Dwidja Priyatno, 2010, Pertanggungjawaban Pidana Korporasi, Prenada Media Group, Jakarta, p.130.

Badan Kordinasi Penanaman Modal (BKPM), "PTSP Pusat Telah Menerbitkan 17.238 Izin", http ://www2.bkpm.go.id>file_siaran pers, last access on 24 December 2016.

D.P. O' Connel, 1970, International Law, Stevens and Sons, London, p.599.

Dwidja Priyatno, 2005, Kapita Selekta Hukum Pidana, STHB Press, Bandung, p.73.

Ibid.

Dwidja Priyatno, "Reorientasi dan Reformulasi Sistem Pertanggungjawaban Pidana Korporasi Dalam Kebijakan Kriminal dan Kebijakan Hukum Pidana," Jurnal Syiar Hukum, Vol.9, No. 3, 2007, p. 208.
} 
is included in the criminal offence of corruption. Criminal charges and prosecution in enforcing the liability of corporate crime are regulated in Article 20 of the Law No. 31 of 1999 as has been amended through the Law No. 20 of 2001 on Corruption Eradication.

The regulation regarding the jurisdiction to prosecute a corporation under Indonesian criminal law is regulated in Article 2 KUHP. Whereas in the United States Anti-Bribery FCPA, it is regulated as follows:

(g) Alternative Jurisdiction

(1) It shall also be unlawful for any issuer organized under the laws of the United States, or a State, territory, possession, or commonwealth of the United States or a political subdivision thereof and which has a class of securities registered pursuant to section 12 of this title or which is required to file reports under section 15(d) of this title, or for any United States person that is an officer, director, employee, or agent of such issuer or a stockholder thereof acting on behalf of such issuer, to corruptly do any act outside the United States in furtherance of an offer, payment, promise to pay, or authorization of the payment of any money, or offer, gift, promise to give, or authorization of the giving of anything of value to any of the persons or entities set forth in paragraphs (1), (2), and (3) of this subsection (a) of this section for the purposes set forth therein, irrespective of whether such issuer or such officer, director, employee, agent, or stockholder makes use of the mails or any means or instrumentality of interstate commerce in furtherance of such offer, gift, payment, promise, or authorization.

It shall also be unlawful for any United States person to corruptly do any act outside the United States in furtherance of an offer, payment, promise to pay, or authorization of the payment of any money, or offer, gift, promise to give, or authorization of the giving of anything of value to any of the persons or entities set forth in paragraphs (1), (2), and (3) of subsection (a), for the purposes set forth therein, irrespective of whether such United States person makes use of the mails or any means or instrumentality of interstate commerce in furtherance of such offer, gift, payment, promise, or authorization.

In the abovementioned bribery case of $\mathrm{M}$ Corporation to the politicians and the member of Indonesia House of Representative, although the $\mathrm{M}$ Corporation's establishment domicile (lex domicile) is in Japan, and the locus and tempus delicti, as well as its victims, are the State of Indonesia, however considering that $\mathrm{M}$ Corporation also conducted its business and has many partners in the United States, such case has become a "link-point" 29 of the dispute of criminal law jurisdiction between Article 2 of Indonesia KUHP and the jurisdiction in the US Anti-Bribery FCPA. According to jurisdiction stipulations in the US Anti-Bribery FCPA, every corporation conducts its business in the US shall obey every norm, prohibition, and order that is regulated under such act, including its business activities abroad.

However, if it is reviewed from the territorial principle that is applicable universally, it shall be the jurisdiction of Indonesia that applies. In line with the abovementioned Andi Hamzah's argument, it can be interpreted that the territorial principle shows that every corporation that conducts criminal act in the territory where a criminal law applies shall obey such law on such respective State. Indonesia applies the principle that sets the place or region as the standard whereas the lex domicile of the corporation itself is not disputed. Hence, since the link-point from the elements of locus delicti or locus criminis, tempus delicti, lex locus contractus, lex loci solusionis as well as the victims are strongly lead to Indonesian jurisdiction, thus the jurisdiction of lex loci delicti commissi or the law where the crime takes scene that shall be applied is the Indonesian criminal law.

According to I Wayan Partiana, from the

To determine the lex loci delicti commissi or the law from where the crime took place that is applied towards an international criminal act, it shall be seen the strength of the facts of the link-point, among others: Locus delicti, tempus delicti, lex locus contractus, lex loci solusionis, and victim, not lex domicile. 
view of international law, every State's sovereignty has two sides; internal and external. The internal side of the State sovereignty delivers the territorial sovereignty. On the other hand, the external side is a condition where the living States coexist with one another, embracing the equality where the rights and obligations are mutual among nations and they have the ability to establish relationships and equivalent positions with one another. ${ }^{30}$ Although the "linkpoint" of the jurisdiction of Indonesia criminal law in such case is stronger than the jurisdiction of the United States Anti-Bribery FCPA, however, because of such slow prosecution process towards "M Corporation" in Indonesia, it had lost its momentum in enforcing its corporate crime liability once the United States had firstly prosecuted such corporation and punishing fantastic amount of penalty, $\$ 88$ million USD and brought implication to ne bis in idem in Article 76 KUHP.

3. The Position of Ne Bis In Idem Principle in National and International Criminal Law

a. The Principle of $\mathrm{Ne}$ bis in idem and Its Relation with Territorial Principle in the Context of the National Criminal Law of Indonesia

From the perspective of the national criminal law of Indonesia, there are at least two principles stipulated explicitly in such respective law, namely: the territorial principle in Article 2 KUHP and the principle of ne bis in idem in Article 76 KUHP which is crucial to be taken into account in the bribery case of $\mathrm{M}$ Corporation. This application of territorial principle and ne bis in idem principle will underlie the principles of State authority to allow (or not) the jurisdiction of its criminal law in prosecuting the corporation as the perpetrator of such criminal act.

The territorial principle referred in Article 2 KUHP emphasizes that the jurisdiction of Indonesia criminal law applies to every person or corporation that has performed a criminal act in the territory of Indonesia as a form of the sovereignty of the State of Indonesia in its territory. According to Eddy O.S. Hiariej "[...] it is based on a postulate interest reipublicae ne maleficia remaneant impunita. Meaning that there is an interest of a State so that a crime that took place in its territory does not go unpunished". ${ }^{31}$ So is the case with the argument of van Hamel who says, according to the territorial principle, the criminal law of a State will rule the action that is performed within the State's borders, where based on its character is not depending on the nationality of the perpetrator or the legal interest that is attacked. ${ }^{32}$ In other words, tempus and locus delicti are the essential elements in determining the territorial principle, whereas the State origin of the corporation will not be prioritized.

In addition to tempus and locus delicti, the current development on the enforcement the corporate crime law also considers the position of the victim ${ }^{33}$ from the perpetrator of the criminal act. In this case, considering the consideration part of the Law No. 31 of 1999 as has been amended by the Law No. 20 of 2001 on Corruption Eradication letter $\mathrm{a}$ and $\mathrm{b}$ as the legis ratio, the victim from the criminal act that had been done by M Corporation was the Indonesian people. Such bribery act was an extensive violation towards the social and economic rights of the people of Indonesia. Therefore, the obligation to prosecute $\mathrm{M}$ Corporation shall be under the jurisdiction of Indonesian law as a realization of protection

\footnotetext{
I Wayan Partiana, 2004, Hukum Pidana Internasional dan Ekstradisi, Yrama Widya, Bandung, p.12.

See Article 20 Republic of Indonesia Supreme Court Regulation No 13 of 2016 which stipulates "For the loss borne by the victims as the impact of the crime done by the Corporation can be indemnified through the restitution mechanism in accordance with the provisions of the laws and regulations that apply or through a civil claim"
} 
to the social and economic rights of the people of Indonesia who become the victim of $\mathrm{M}$ Corporation's criminal act as well as become a manifestation of territorial principle.

Hence, besides tempus delicti and locus delicti, the victim of the crime is also an important element to strengthen the territorial principle to determine the authority in applying the sovereignty of a State's national criminal law. However, although the power of a territorial principle is essential in national criminal law, it does not necessarily mean that such principle will be directly applicable, but shall be referred first to other relevant principles, such as ne bis in idem. Wirjono Prodjodikoro states "[...] Paragraph 2 of Article 76 KUHP determines that in case a gewijsde decision is taken by a foreign court; thus the second prosecution is not allowed based on the principle of ne bis in idem". ${ }^{34}$ Therefore, there is an exception that resulted to the invalidity of the territorial principle, namely when it is in contradiction with the principle of ne bis Idem, when such case has been firstly decided by other State's court and already has a legal binding power.

\section{b. Ne Bis in Idem Principle in the Context of International Criminal Law}

Since the born of modernism, multinational corporations tend to dominate the transnational business relationship. Therefore, even though the parent company of a multinational corporation located in a State, because the operational working area of such corporation is situated in many other States, it has many subsidiaries in those states as its representatives in doing business. Such situation has affected the universal principle of the international criminal law when such respective corporation conducts a bribery, corruption or other criminal act in other states. Furthermore, since the enactment of the United Nations Convention Against Corruption (UNCAC) in 2003, the criminal act of bribery by corporation towards foreign officials and politicians has been agreed as an international crime.

Again, according to Eddy O.S. Hiariej "[...] The significant meaning of the universal principle is that there should be no perpetrator of an international crime who is freed from punishment. Since then, every country has a right to arrest, prosecute and punish such perpetrator of an international crime. However, if a perpetrator of the international crime has been prosecuted and punished by a State, thus another State is prohibited from prosecuting and punishing him for the same case". ${ }^{35}$ Hence, the implementation of the universal principle in international criminal law respects and takes the importance of ne bis in idem into account so that there is a balance between the legal certainty and justice in handling the case of corporate crime.

Therefore, considering that $\mathrm{M}$ Corporation also conducts its business in many countries, including the United States, the State also reserves its right to use its criminal law jurisdiction upon the corporate criminal act done by $\mathrm{M}$ Corporation per the provisions of Anti-bribery FCPA and to ask its liability before the United States' court. The enactment of The United States Antibribery FCPA that also adheres the universal principle is the State's response to eradicate the act of corruption in all around the world. On the one hand, US corporations are experiencing disadvantages in business competition because it is considered as unlawful act and prohibited according to the US law to

Wirjono Prodjodikoro, 1986, Asas-asas Hukum Pidana di Indonesia, Eresco, Bandung, p. 155.

Eddy O.S. Hiariej, 2016, Prinsip-prinsip Hukum Pidana, Edisi Revisi, Cahaya Atma Pustaka, Yogyakarta, p. 312. 
bribe the foreign officials. However, on the other hand, the multinational corporations from other State are innocent in doing such practice since they consider it as a business tradition by using the philosophy of "to make everybody happy" to fulfil their interest.

The universal principle in Anti-Bribery FCPA becomes a door for the jurisdiction of US criminal law in the case of a corporate crime of $\mathrm{M}$ Corporation, although the tempus, locus delicti as well as the victims are the State of Indonesia. Further, in the investigation process by the Prosecutor of the US Department of Justice, such corporation was agreed to pay the crime penalty of $\$ 88$ million USD. The punishment that might be obtained by $\mathrm{M}$. Corporation if it was prosecuted in Indonesia was more lenient than what it got when it was prosecuted in the United States. As stipulated in the Article charged, it would only be obliged to pay the minimum amount of penalty in the amount of 50 million rupiahs or equal to $\$ 3,846$ USD (Rate 13,000 rupiahs/\$1USD) or with the maximum amount of penalty, in the amount of 250 million rupiahs or equal to $\$ 19,230$ USD as has been stipulated in Article 5 of the Law on Corruption Eradication in Indonesia.

Such comparison of to the penalty that had been applied by the United States, namely of $\$ 88$ million USD also became the consideration of the United States to pursue the perpetrator of the corporate crime, the M Corporation to the court of the United States. It was needed to create a deterrent effect for it. Unfortunately, such act of the United States had brought bad implication to the enforcement of the corporate crime law in Indonesia since it did not consider the jurisdiction power based on the territorial principle of Indonesia. The guilty plea of M. Corporation that had a legal binding force has made such criminal act comes under the principle of ne bis in idem and cannot be reprosecuted in Indonesia.

\section{The Criminalization of Bribery Perpe- trator associated with the Principle of $\mathrm{Ne}$ Bis In Idem}

The prosecution of M. Corporation Japan in the US Criminal Justice System although its locus and tempus delicti, as well as its victims, are the State of Indonesia has brought the sense of paradox for the character of the Law on Corruption Eradication. The law that is known extraordinary has obtained a sense of extraordinary graceful in enforcing the liability towards the corporate criminal act. It also harms the territorial principle as stipulated in KUHP since it gives an impression that Indonesia is incapable and had failed to uphold its jurisdiction to prosecute. Such case has legal implications as well towards the principle of ne bis in idem.

Satjipto Raharjo contends that a principle is something essential in law enforcement. ${ }^{36}$ Lexically, the principle means something that becomes a foundation to think or act that sustaining the sturdiness of a legal norm. ${ }^{37}$ The principle of ne bis in idem is one of the fundamental principles which means that somebody is not allowed to be prosecuted and punished for more than once for the same crime. ${ }^{38} \mathrm{Ne}$ bis in idem is a legal principle that becomes the basis for the establishment of the rule of law (it is the ratio legis of the laws and regulations). ${ }^{39}$ It is often mentioned as the heart of the law that becomes a reference for the real meaning of the law product in its implementation (inconcreto). The implementation of the principle of ne bis in idem in the prosecution of a corporation as the perpetrator of a criminal act of bribery is something essential in Indonesia criminal law since such principle is clearly codified as the judicial 
basis in the material criminal law.

The juridical basis of the implementation of ne bis in idem in Indonesia criminal law system, associated with the liability of the corporation as the perpetrator of the bribery is regulated in Chapter VIII, Article 76 paragraph (1), (2) KUHP ${ }^{40}$ that regulates the forfeiture of the right to prosecute and the eradication of the punishment towards a corporation. It is stipulated in this Article the meaning of the legal principle known as ne bis in idem as "corporation/person cannot be prosecuted once again in case its/his criminal act has been decided by Judge. The implementation of such principle in Indonesia criminal law depends on the fact that, whether there has been a judgment made by Judge towards such corporation, regarding certain events that already has legal binding force (in kracht van gewijsde).

Regarding such matter, Eddy O.S. Hiariej contends that on such a quo article, there are two adagium contained within. First, nemo debet his vexari which means that no one is allowed to be disturbed with two-times prosecution for the same case. This adagium is later known as ne bis in idem which proximately means, someone cannot be prosecuted for the second time before the court with the same case. Second, nihil in lege intolerabilius est (quam) eandem rem diverso jure censeri. Meaning that the law will not be allowed the same case to be prosecuted in several trials. ${ }^{41}$

There are three reasons that underlie both of the adagium; First, to protect the honour and nobility of the Judge's prestige that has decided a case. Res judicata in criminalibus; A judgment in a criminal case that already has a legal binding force is final, so it closes all rights to ensure or continue the prosecution regardless such judgment is right or wrong. The judge is not forced to recurrence examining a case or contradict the perspectives of other judges. Second, to sustain the human rights. In this regard, it is the interest of the individual not to be disturbed over the case that has been prosecuted and already has legal binding force. Third, the State in maintaining its prestige shall give legal certainty. ${ }^{42}$

Other judicial reason that also emphasizes the importance of judge in noticing the implementation of the principle of ne bis in idem in handling corporate crime as well as strengthening the principle in Article $76 \mathrm{KUHP}$ is the issuance of the Supreme Court Circular Letter No. 03 of 2002 on the Case Handling Concerning Ne Bis In Idem. It is purposed giving legal certainty for the justice seekers by avoiding the possibility of different judgment; First, when the process in the same Court: (a) the Clerk shall be thorough in examining the documents of the case and reporting to the Head of the Court if there is similar case that has been decided in the past; (b) The Head of the Court shall give notes to the Panel of Judges regarding such matter; and (c) the Panel of Judges shall consider both the interlocutory judgement and judgment on the matter of the case regarding similar case that has been decided. Second, that in the matter of the case regarding a similar case that has been decided in the past. If it is processed in different court domains: a) The respective clerk shall inform the Court where such case has been decided; and b) report to the respective Head of the Court regarding the case that is related to ne bis in idem. Third, the delivery process to the Supreme Court. Such respective court shall report to the Supreme Court regarding the case that is related to the principle of ne bis in idem.

A judgment that already has legal binding force will fulfil the principle of ne bis in idem so it cannot be prosecuted again in the case of; a) Sentence: the Judge decides that the defendant

40 Article 76 KUHP paragraph (1) stipulates; Except for the cases where judicial verdicts are subject to revision, no person shall be prosecuted again by reason of an act which the verdict of an Indonesian judge with respect to him has become final. By Indonesian judge shall also be understood the justice of the Adat Law tribunals at places where such courts exist. Whereas paragraph (2) stipulates: If the final verdict comes from another judge, no prosecution shall take place against the same person because of the same act in case of 1. Acquittal or lapse of time from prosecution; 2 . The sentence followed by a completed execution, grace or lapse of time from punishment.

41 Eddy O.S. Hiariej, Op. cit., p. 422

42 Ibid., p. 423. 
clearly has done a criminal act that is accused on him, b) Exemption from all charges: the act accused to the defendant is proven guilty, but such event is not a criminal act, and c) Acquittal Judgment: That the fault of the defendant over the criminal act accused on him is not proven enough, so the Judge grants his acquittal.

The court judgment that can be classified as $n e$ bis in idem is the judge's judgment in a criminal case that is in the form of; a) Judgment of Acquittal (Vrijspraak), b) Release Judgment/ Exemption from All Prosecution (onstlag van alle rechtsvolging), and c) Sentence Judgment (Veroordeling). Therefore, according to the writer, although the decision in the case of M. Corporation was made within the jurisdiction of the United States Criminal Justice System, however the case criteria of M. Corporation can be categorized as a case where ne bis in idem shall be applicable since the legal reasoning of such judgment already has legal binding force, it has been examined, prosecuted and sentenced by the court, with the same criminal act, defendant, corporation/ person and tempus and locus delicti.

The criteria of tempus and locus delicti in determining and applying a case as ne bis in idem are essential in a criminal act since as stipulated in Indonesia Code of Criminal Procedure (Kitab Undang-Undang Hukum Acara Pidana - KUHAP) that the Prosecutor prepares the indictment by "elaborating thoroughly, clearly, and completely regarding the criminal act that is charged by stating the time and place when the crime is being committed". ${ }^{43}$ The non-fulfilment of the criteria of locus and tempus delicti on the indictment is stipulated as follows "The indictment that does not fulfil the requirements as referred in paragraph (2) letter $\mathrm{b}$ will be null and void. ${ }^{44}$ By stating a thorough, clear and complete elaboration regarding the criminal act accused including the time and place where such crime has been committed by the corporation as the perpetrator, as well as mentioning the identity of such corporation, it can be easily identified whether such case is an identical criminal case which later brings consequence, it is a ne bis in idem.

According to Yahya Harahap, one of the reasons for prosecution termination is because the case has been set aside (the case is closed for the sake of law). The prosecution termination for the sake of law means that the defendant of a criminal case has been freed from all charges by the law and in accordance with it, such case shall be closed, or its examination shall be stopped in all stages. The legal reasoning that makes a case is closed for the sake of the law can be based on, among others; because of the decease of the defendant, ne bis in idem, and expiration. ${ }^{45}$ From such argument of Yahya Harahap, the writer underlines the basis of ne bis in idem, so that in the prosecution of the corporation as the perpetrator of the criminal act of bribery is not prevalent to be reinvestigated by the Police, Prosecutor, or the Anti-Corruption Commission within Indonesia judiciary system. The advocate or the corporation who becomes the defendant can also use this principle of ne bis in idem as a basis for a basis for a plea in the hearing, in case the investigator and the prosecutor resubmit the defendant for the same criminal act which has previously been decided by Judge and has legal binding power.

Based on the reason of ne bis in idem, a case that is examined by the court can be stopped from its examination and prosecution if ne bis ini idem is found. If there is a case of ne bis in idem that remains brought to the court, a Judge shall decide that the prosecutor's charges cannot be accepted. ${ }^{46}$ Meaning that, the Judge who examines a corporation case, where the corporation was found to have ever received the same verdict and already has legal binding force as a form of abovementioned judgment

\footnotetext{
Article 143 paragraph (2) letter b Indonesia Code of Criminal Procedure (KUHAP).

Article 143 paragraph (3) Indonesia Code of Criminal Procedure (KUHAP).

Yahya Harahap, 2002, Pembahasan Permasalahan dan Penerapan KUHAP, Penyidikan dan Penuntutan, Sinar Grafika, Jakarta, p. $437-438$.

Mifthakul Huda, "Ne Bis In Idem,” Majalah Konstitusi, Berita Mahkamah Konstitusi, No. 28 April 2009 , p.76.
} 
but still filed for re-examination in court, is able to reject or not accepting to prosecute such case with legal consideration of ne bis in idem whose judicial basis is Article 76 KUHP and philosophical basis of it, is for the sake of legal certainty.

In criminal law, this principle of ne bis in idem is absolutely needed since "there shall be an end to the investigation/prosecution, and the end of the enactment of criminal provisions against crime." The principle of $\mathrm{Ne}$ bis in idem becomes a guide so that there is no more examination/prosecution towards the same corporation from a criminal act that has been decided and had legal binding force. As a result, the existence of two judgments towards the same perpetrator and the same act can be avoided. It also avoids the investigation/prosecution process towards the same perpetrator when in fact there has been a court decision that has a legal binding force. Hence, a fair legal certainty can be achieved.

The United States that has a different legal system with Indonesia, (the common law whereas Indonesia applies civil law), also uses similar principle to the principle of ne bis in idem in the prosecution of a corporation as the bribery perpetrator. The principle that is similar but different is the principle of double jeopardy that is regulated in the fifth amendment of the US Constitution that stipulates "nor shall any person be subject for the same offense to be twice put in jeopardy of life or limb." The principle of Double Jeopardy can be applied: when the panel of juries in a jury trial, when the first witness is sworn in the bench, or when the guilty confession or plea is given. Double Jeopardy covers four different prohibitions, such as: (a) the next prosecution after acquittal, (b) the next prosecution after punishment, (c) the next prosecution after the cancellation of a certain trial, and (d) double punishment within the same prosecution.

The purpose of the implementation of double jeopardy is similar to ne bis in idem in the prosecution of a corporation as the bribery perpetrator in Indonesia and the United States. It is a universal principle that prevails, is acknowledged and respected in international law, including in the positive criminal law of nations. The criminal justice system and the criminal justice procedures of the US respect and apply this principle seriously. A corporation that has ever been prosecuted and tried for a criminal act is not allowed to be prosecuted for the second time for the same criminal act. Meaning that the structural institution of the US criminal justice system such as the Police, FBI, Prosecutor, and Court identify and take into account the double jeopardy case for the sake of legal certainty.

The former Attorney in General Agung Basrief Arif states that the difference between double jeopardy and ne bis in idem is that Ne bis in idem as referred in Article 76 KUHP that somebody is not allowed to be prosecuted two times for the same action that previously has been decided by Judge. Whereas double jeopardy is a procedure in the defendant's pleading that he cannot be prosecuted again based on the same prosecution on a judgment that has been decided by Judge. ${ }^{47}$ Although Double Jeopardy is not known under Indonesian legal system, but according to US writer, in the State of its origin, it also rarely happens since the prosecutor is usually always trying to elaborate all elements of the charges that can be applied in one trial process in avoiding the escape of the corporation as the perpetrator of the criminal act just because the elements of the charges are not fulfilled and has to be freed from all charges.

The case of M Corporation that was examined according to the jurisdiction of The United States Anti-Bribery FCPA had not yet entered a trial since such corporation had already pleaded guilty before the Prosecutor of Federal Bureau Investigation (FBI) the Department of Justice which announced the guilty verdict on Wednesday, 19 March 2014 which basically stating that $\mathrm{M}$ Corporation agreed to plead guilty for the act of bribery in the steamelectric power plant project in Tarahan Indonesia. 
The prosecutors in the federal system is a part of the executive of the Department of Justice of the United States, appointed by the President after obtaining approval from the Senate. The Attorney General in federal districts are known as the US Attorneys, and they are also appointed by the President and approved by the Senate. In the Department of Justice, there is also the FBI that investigates all crimes pointed to the United States. Every State in the US has an Attorney General as the branch of the executive who is usually chosen by the local people as well as prosecutors who are disseminated in all over the country called as the State Attorney/ District Attorney who is selected as well. ${ }^{48}$

In Indonesia, this announcement from the US Department of Justice also became a debate and responded with various opinions from legal scholars who considered that such guilty plea was a momentum for the Anti-Corruption Commission (KPK) to be able to investigate thoroughly and punish the corporation as the perpetrator of the bribery act. KPK is supposed to use the guilty plea of M Corporation and the verdict from the US Department of Justice that had punished the corporation to pay the penalty of $\$ 88$ million USD as an authentic proof to further investigate it in Indonesia.

However, the legal debate with such legal reasoning above is no longer relevant to be applied to follow up such case further. On one hand, the writer agrees that the corporation as the perpetrator should be punished and Indonesia should maintain its legal sovereignty in front of the international world, however, on the other hand, according to the writer, such guilty announcement by the Department of Justice of the United State is a shutdown for the prestige of Indonesia Criminal Law in such case. Indonesia had lost its momentum because of the guilty verdict that had preceded the decision of Corruption Court in Indonesia that had directly affected Indonesia criminal law principle. Consequently, the follow-up of the prosecution of such corporation in Indonesia was stopped because in contradiction with the principle of $\mathrm{Ne}$ bis in idem that was still conservatively acknowledged in Indonesia criminal law.

The Schengen Convention prevents two States or more that have jurisdiction link to prosecute the same criminal act for the second time. In Article 54 of this Convention regarding the application of the ne bis in idem principle, it is stipulated that if a punishment has been given and applied thus another member State is not allowed to prosecute for the same criminal act. ${ }^{49}$ The implementation of $\mathrm{Ne}$ bis in idem or also known as Non bis in idem in the prosecution of corporate crime in Indonesia has a meaning that such corporation cannot be investigated for the second time for the same criminal act in Indonesia. Such stipulation is based on the consideration that one day there shall be an end to the investigation/prosecution and the end of the enactment of criminal provisions against a certain crime. This principle is a guide so that there is no more investigation/prosecution of the same perpetrator in the same criminal act that has been previously decided by Judge and already obtained a final judgment. In other words, it is purposed to avoid the existence of two judgments against the same perpetrator in the same criminal act. It is also purposed to avoid the effort to investigate/prosecute the same perpetrator and criminal act where previously there has been a judgment that already has a legal binding force (in kracht van gewijsde).

In International Criminal Court (ICC), there is also a stipulation of Ne bis in idem. The institution of ICC that essentially purposed to overcome extraordinary crime that becomes a threat to the international peace and security and world welfare. The international provisions that regulate ne bis in

\footnotetext{
48 See, Pusat Kehakiman Federal, "Sistem Hukum di Amerika Serikat, Sebuah Penjelasan Singkat," http://www:fjc.gov/public/pdf.nsf/lookup/ Indonesian01.pdf/\$file/Indonesian01.pdf, last access on 2 February 2015.

49 RN Daniels, Made Putri Saraswati and A.A. Gede Oka Parwata, "Penerapan Asas Ne Bis In Idem Dalam Hukum Pidana Internasional", Jurnal Kertha Nagara, Vol. 2, No. 3, May 2014, pp. 3-4.
} 
idem contained in the International Covenant on Civil and Political Rights (ICCPR) that emphasizes that "No one shall be liable to be tried or punished again for an offence for which he has already been finally convicted or acquitted in accordance with the law and penal procedure of each country." It is also in accordance with the Protocol No. 7 of The Convention for the Protection of Human Rights and Fundamental Freedoms as amended by Protocol No. 11, Article 4 on the right not to be tried or punished twice.

This legal implication is what the writer argues can happen on the continuation of the prosecution of $\mathrm{M}$ Corporation as the bribery perpetrator under Indonesia criminal jurisdiction system. The implementation of ne bis in idem principle in the law enforcement of corporate crime in Indonesia is something absolute to be obeyed, so that such corporation is no longer able to be processed in every structure of Indonesia criminal jurisdiction system. It means that through such guilty judgment from the United States Department of Justice, such case is not able to be investigated, charged and prosecuted in Indonesia because of $\mathrm{Ne}$ Bis In Idem.

\section{Conclusion}

From the abovementioned elaboration, it can be concluded. First, the development of the sociology of corporation has become more tendentious to perform a criminal act in doing its business. Therefore, several policies shall be made as a solution. In Indonesia, the short-term solution that has been done by the government to eliminate the corporation's bribery act is by integrating the administration of corporation licensing through the systematic establishment of One-Stop Service (PTSP) in the Indonesia Investment Coordinating
Board (BKPM). The medium-term solution is through the policy of legal reformation by the issuance of Presidential Regulation No. 87 of 2016 on The Special Task Force to Eradicate Illegal Levies - Satuan Tugas Sapu Bersih Pungutan Liar (SABER PUNGLI). Whereas for the long-term solution, the writer is suggesting for the enactment of legal reformation to systemize the law enforcement particularly for the corporate crime whether from its legal substance, legal structure, or legal culture integrally.

Second, if there is a jurisdiction dispute or a corporate criminal act that has international sense, the way to determine lex loci delicti commissi or the law where the crime took scene that will be applied is by deciding stronger link points, namely: locus delicti, tempus delicti, lex locus contractus, lex loci solutionis, victim, and not lex domicile. Thus, in the corporation case above, the lex loci delicti commissi that shall be applied is the jurisdiction of Indonesia criminal law. Third, the position of Ne Bis In Idem principle in national and international criminal law is important in deciding whether a state enforces the territorial principle and the universal principle of its criminal law. A case of corporate crime that has been decided by a court of a State cannot be re-prosecuted by other State because of Ne Bis In Idem. Fourth, the prosecution of M Corporation which was based on the Anti-bribery FCPA in the Criminal Justice System of the Department of Justice of the United States has brought bad implication towards the jurisdiction of the corporate criminal liability enforcement in Indonesia Criminal Justice System, in which although the bribery beneficiaries have been prosecuted in the Corruption Court in Indonesia, but the corporation as the perpetrator of the bribery cannot be held liable for its criminal act because of the principle of Ne bis In Idem.

\section{REFERENCES}

\section{A. Books}

Connel, D.P. O', 1970, International Law, Stevens and Sons, London.
Daliyo, J.B., et al., 1994, Pengantar Ilmu Hukum, Buku Panduan Mahasiswa, Gramedia Pustaka Utama, Jakarta. 
Hamzah, Andi, 2008, Asas-asas Hukum Pidana, Rineka Cipta, Jakarta.

Harahap, Yahya 2002, Pembahasan Permasalahan dan Penerapan KUHAP, Penyidikan dan Penuntutan, Sinar Grafika, Jakarta.

Hiariej, Eddy O.S., 2016, Prinsip-prinsip Hukum Pidana, Edisi Revisi, Cahaya Atma Pustaka, Yogyakarta.

Kochan, Nick, dan Goodyear, Robin, 2011, Corruption, The New Corporate Challenge, Pallgrave Macmillan, New York.

Muladi, dan Priyatno, Dwidja, 2010, Pertanggungjawaban Pidana Korporasi, Prenada Media Group, Jakarta.

Parthiana, I Wayan, 1990, Ekstradisi dalam Hukum Internasional dan Hukum Nasional Indonesia, Penerbit Mandar Maju, Bandung.

Partiana, I Wayan, 2004, Hukum Pidana Internasional dan Ekstradisi, Yrama Widya, Bandung.

Priyatno, Dwidja, 2005, Kapita Selekta Hukum Pidana, STHB Press, Bandung.

Rahardjo, Satjipto, 2006, Ilmu hukum, Citra Aditya Bakti, Bandung.

Sahetapy, J.E., 1994, Kejahatan Korporasi, Refika Aditama, Bandung.

Sembiring, Sentosa, 2014, Hukum Dagang, Citra Aditya Bakti, Bandung.

Sugiharto, Bambang, et al., 2013, Humanisme dan Humaniora, Seri buku Humaniora UNPAR, Matahari, Bandung.

Wilske, Stephen, dan Schiller, Theresa, 1997, "International Jurisdiction In Ciberspace: Which States may regulate the internet, 50 Fed.Com. L.J.

Wirjono Prodjodikoro, 1986, Asas-asas Hukum Pidana di Indonesia, Eresco, Bandung.

\section{B. Journal Articles}

Muskibah, "Tanggung Jawab Direksi Dalam Penerapan Prinsip Good Corporate Governance," Jurnal Ilmu Hukum, Vol. 2, No. 3, 2010.

Priyatno, Dwidja, "Reorientasi dan Reformulasi
Sistem Pertanggungjawaban Pidana Korporasi Dalam Kebijakan Kriminal dan Kebijakan Hukum Pidana", Jurnal Syiar Hukum, Vol. 9, No. 3, 2007.

Putri Saraswati, Made, dan Parwata, A.A Gede Oka, 'Penerapan Asas Ne Bis In Idem Dalam Hukum Pidana Internasional”, Jurnal Kertha Nagara, Vol. 2, No. 3, May 2014.

Rifai, Eddy, "Perspektif Pertanggungjawaban Pidana Korporasi Sebagai Pelaku Tindak Pidana Korupsi", Jurnal Mimbar Hukum, Vol. 26, No.1, February 2014.

Yurico Bawole, Grace, "Penerapan Sistem Hukum Pidana Civil law dan Common Law Terhadap Penanggulangan Kejahatan Korporasi”, Jurnal Lex Crimen, Vol. III, No. 3, May-July 2014.

\section{Magazine and Newspaper}

Huda, Mifthakul, "Ne bis in idem”, Majalah Konstitusi, Berita Mahkamah Konstitusi, No. 28 April 2009.

\section{Internet Articles}

Badan Kordinasi Penanaman Modal (BKPM), "PTSP Pusat Telah Menerbitkan 17.238 Izin", http ://www2.bkpm.go.id >file_siaran pers $>$, last access on 24 December 2016.

The United States Department of Justice, "Marubeni Corporation Agrees to Plead Guilty to Foreign Bribery Charges and to Pay an $\$ 88$ Million Fine", , last access on 24 December 2016.

Putra, Gilang Aji, "Apa Sebenarnya Penyebab Kekalahan Jerman di Perang Dunia II?,Kompas, m.kompasiana.com/ gilangajiputra/apa-sebenarnya-penyebabkekalahan-jerman-di-perang-dunia-II, last access on 19 December 2016.

Hukum Online, "Ne bis in idem", //www. hukumonline.com/ klinik/ detail/cl1193 /nebis-in-idem, last access on 9 October 2016.

Koran Jakarta, "KPK Mesti Tuntaskan Kasus Marubeni”, last access on 24 Desember 2016. 
KPK, “Emir Moeis Divonis \# Tahun Penjara”, http:// www.kpk.go.id/id/berital berita-sub/1794, Emir Moeis divonis 3 tahun penjara, Komisi Pemberantasan Korupsi (KPK), last access on 24 December 2016.

Pusat Kehakiman Federal, "Sistem hukum di Amerika Serikat, sebuah penjelasan singkat",http://www.fjc.gov/public/pdf.nsf/ lookup/Indonesian01.pdf/\$file/Indonesian01. $p d f$, last access on 2 February 2015.

Wikipedia, "Developmentalisme", https. //id.m. wikipedia. org. wiki developmentalisme, last access on 19 December 2016.

\section{E. Regulations}

Temporary People's Consultative Assembly Decree No. XXIII/66 on the Renewal of Policy on Economic Foundation of Finance and Development.

Law Number 1 of 1946 Jo. Law No. 73 of 1958 on the Entry into Force Declaration of the Law No. 1 of 1946 on the Regulation of Criminal Law for The Whole Region of Republic Indonesia and Amending the Criminal Code
(State Gazette of the Republic of Indonesia Year 1958 Number 127, Supplement of State Gazette of the Republic of Indonesia Number 1660).

Law Number 8 of 1981 on Criminal Procedural Law (State Gazette of the Republic of Indonesia Year 1981 Number 76, Supplement of State Gazette of the Republic of Indonesia Number 3209).

Law Number 31 of 1999 as has been amended through the Law Number 20 of 2001 on the Corruption Eradication (State Gazette of the Republic of Indonesia Year 1999 Number 140, Supplement of State Gazette of the Republic of Indonesia Number 3874, and State Gazette of the Republic of Indonesia Year 2001 Number 134, Supplement of State Gazette of the Republic of Indonesia Number 4150).

\section{F. Others}

The United States Anti-Bribery and Books \& Records Provisions of The Foreign Corrupt Practices Act 